\title{
Pengaruh Penggunaan Sistem Pembayaran Digital terhadap Perilaku Beralih di Era Pandemi COVID-19
}

\author{
Rasistia Wisandianing Primadineska ${ }^{\bowtie}$ \\ Sekolah Tinggi Ilmu Manajemen YKPN \\ e-mail: primadineska@gmail.com
}

\begin{abstract}
This study aims to examine the effect of changes in individual behavior in the use of electronic payment systems on switching intentions and switching behavior of individuals during the COVID-19 pandemic in Indonesia. Total of 100 respondents from various regions in Indonesia were tested in this study. Most of the respondents are generation $Z$ and millennial. The data were processed using SEM PLS. The results show that during the pandemic, individuals who have already used digital payment systems have the intention of switching from conventional to digital payment systems. The intention to switch has also had a positive effect on the behavior of moving from conventional to digital payment systems. This research adds references to behavioral research related to the development of the payment system in Indonesia, especially during the pandemic.
\end{abstract}

Keywords: COVID-19, digital payment system, switching intention, switching behavior

\begin{abstract}
Abstrak
Penelitian ini bertujuan untuk menguji pengaruh perubahan perilaku individu dalam penggunaan sistem pembayaran elektronik terhadap niat beralih dan perilaku beralih individu selama masa pandemi COVID-19 di Indonesia. Sebanyak 100 responden dari berbagai wilayah di Indonesia diuji dalam penelitian ini. Sebagian besar responden merupakan generasi $\mathrm{Z}$ dan milenial. Data diolah menggunakan SEM PLS. Hasil menunjukkan bahwa selama pandemi, individu yang sudah pernah menggunakan sistem pembayaran digital memiliki niat beralih dari sistem pembayaran konvensional menuju digital. Adanya niat beralih tersebut juga berpengaruh positif terhadap perilaku berpindah dari sistem pembayaran konvensional menuju digital. Penelitian ini menambah referensi penelitian keperilakuan terkait perkembangan sistem pembayaran di Indonesia, khususnya di masa pandemi.
\end{abstract}

Kata kunci: COVID-19, sistem pembayaran digital, niat beralih, perilaku beralih 


\section{PENDAHULUAN}

Pandemi COVID-19 sudah berlangsung di Indonesia lebih dari satu tahun. Kondisi pandemi sedikit banyak mempengaruhi perilaku manusia dalam beberapa hal salah satunya adalah perubahan penggunaan sistem pembayaran konvensional menjadi digital. Menurut data dari Bank Indonesia, selama 2020 transaksi digital menggunakan uang elektronik meningkat 41,2\% dibandingkan tahun 2019 (Lidwina, 2020). Fenomena ini kemudian mendorong Bank Indonesia untuk mengintegrasikan sistem keuangan digital dengan perekonomian RI sesuai dengan tujuan Bank Indonesia untuk menciptakan masyarakat minim kas (cashless society) pada 2024.

Peningkatan transaksi ini diakibatkan oleh terbatasnya kegiatan manusia untuk melakukan transaksi secara konvensional dengan datang ke bank atau ke ATM. Beberapa faktor pendorong penggunaan sistem pembayaran elektronik selain dikarenakan oleh pembatasan mobilitas adalah karena adanya kemudahan dan kompleksitas yang cukup rendah dalam penggunaan sistem pembayaran digital (Iradianty \& Aditya, 2020). Selain itu, sistem pembayaran digital merupakan sistem all-in-one yang dapat digunakan untuk berbagai macam transaksi yang diperlukan dalam kehidupan sehari-hari.

Meningkatnya penggunaan sistem pembayaran digital di era pandemi COVID19, harus diiringi dengan pemahaman konsumen terkait sistem keamanan dan prosedur keamanan yang disediakan oleh para penyedia jasa pembayaran elektronik. Reputasi penyedia jasa pembayaran elektronik merupakan salah satu faktor yang mendorong konsumen atau nasabah untuk menggunakan suatu sistem pembayaran elektronik (Jaya, 2016). Penyedia jasa dengan kondisi keuangan yang stabil serta minim permasalahan pelanggaran etika dalam hal penyebaran data pribadi, kecurangan transaksi, dan juga penyalahgunaan wewenang cenderung akan dipilih nasabah untuk digunakan
(Chellapalli \& Kumar, 2020; Lim dkk., 2007; Urs, 2015).

Penelitian ini bertujuan untuk mengetahui perilaku individu di masa pandemi COVID-19 terhadap penggunaan sistem pembayaran elektronik. Penelitian terdahulu banyak membahas terkait faktorfaktor yang mempengaruhi penggunaan, seperti persepsi keamanan, kepercayaan, juga model penerimaan teknologi (Crowe dkk., 2011; Kim, dkk., 2010; Laudon \& Laudon, 2018), sedangkan penelitian ini mengambil sampel di masa pandemi dan menguji apakah pandemi mendorong perubahan perilaku individu. Perubahan perilaku yang dimaksud adalah penggunaan sistem pembayaran konvensional menjadi digital dan akan terus menggunakan sistem digital ke depannya.

\section{Sistem Pembayaran Elektronik}

Sistem pembayaran elektronik merupakan sistem pembayaran yang memungkinkan seseorang untuk membayar berbagai macam transaksi, memeriksa jumlah saldo, dan melakukan pengiriman dana secara instan yang tidak hanya berasal dari perbankan tetapi juga perusahaan penyedia jasa pembayaran (Iradianty \& Aditya, 2020; Kristensen \& Solvoll, 2019; Muthurasu \& Suganthi, 2019).

Metode pembayaran digital dianggap lebih mudah, simpel, dan memberikan keuntungan apabila penyedia jasa memberikan potongan harga atau diskon pada pembayaran tertentu (Chellapalli \& Kumar, 2020b). Di sisi lain, pembayaran digital juga memiliki risiko keamanan yang mengancam pengguna karena belum seluruh penyedia jasa pembayaran termasuk bank memberikan perlindungan teknis yang memadai. Oleh karena itu, seringkali ditemukan fraud atau kecurangan pada sistem pembayaran digital (Alaeddin dkk., 2018; Zhang dkk., 2019; Peha \& Khamitov, 2004).

Di Indonesia, selama pandemi COVID-19 diketahui terjadi peningkatan transaksi elektronik yang meningkat tajam sebanyak $66 \%$, sedangkan penggunaan 
sistem pembayaran digital meningkat 37,8\% (Ulya, 2020). Kebijakan pemerintah dengan memberlakukan pembatasan sosial membuat individu mencari cara untuk tetap memenuhi kebutuhannya, khususnya dalam hal berbelanja, sehingga sistem pembayaran digital dianggap mudah dan sesuai dengan kebutuhan masyarakat yang mobilitasnya terbatas (Badan Pusat Statistik, 2020b).

\section{Niat Beralih}

Theory of planned behavior menyebutkan bahwa terdapat tiga faktor yang mempengaruhi niat seseorang untuk beralih dari suatu produk atau sistem ke produk atau sistem yang lain. Pertama adalah penilaian seseorang terhadap produk atau sistem yang pernah ia gunakan. Kedua adalah pengaruh dari lingkungan sosial apakah mendukung untuk menggunakan produk atau sistem tersebut. Ketiga adalah persepsi kemudahan dalam penggunaan yang dapat dirasakan ketika ada pengalaman yang pernah dialami (Ajzen, 1991; Astuti \& Eliana, 2019; Jaya, 2016).

Salah satu faktor yang mendorong perilaku beralih individu pada penggunaan suatu sistem adalah adanya kepuasan ketika menggunakan sistem yang baru. Kepuasan timbul apabila harapan sesuai dengan kenyataan yang ditimbulkan dengan penggunaan sistem baru tersebut. Faktor yang berpengaruh secara langsung pada niat beralih adalah penilaian dari individu itu sendiri atas pengalaman yang diperoleh ketika menggunakan sesuatu yang baru (Han dkk., 2011; Jaya, 2016).

Beberapa penelitian terdahulu juga menyebutkan bahwa dalam mencapai niat beralih, selain karena adanya dorongan untuk beralih, juga dipertimbangkan adanya hambatan yang dapat mengurangi niat individu untuk beralih (Alaeddin dkk., 2018; Han dkk., 2011; Xu dkk., 2017). Namun demikian, sistem pembayaran digital pada umumnya tidak menimbulkan hambatan yang besar ketika individu memutuskan untuk beralih dari sistem konvensional menuju digital. Dari sisi switching cost, penggunaan sistem pembayaran elektronik justru dinilai lebih murah dan effortless jika dibandingkan dengan sistem pembayaran konvensional (Oney dkk., 2017; Sagayarani, 2017; Thiab \& Yusoh, 2018). Berdasarkan uraian di atas, maka diperoleh hipotesis sebagai berikut:

$\mathrm{H}_{1}$ : Penggunaan sistem pembayaran elektronik di masa pandemi akan berpengaruh positif pada niat beralih dari sistem pembayaran konvensional menuju sistem pembayaran elektronik

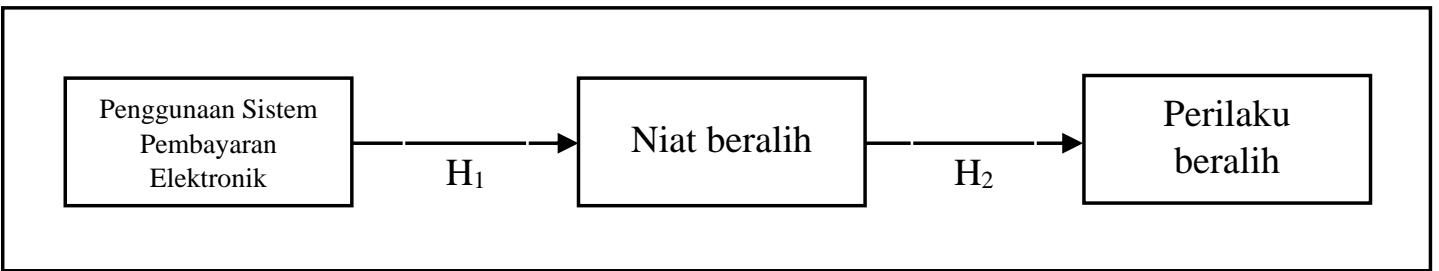

Gambar 1. Kerangka Penelitian

\section{Perilaku Beralih}

Beberapa faktor yang dapat mempengaruhi perilaku beralih antara lain adanya kepuasan, yaitu nilai baru yang diperoleh saat penggunaan suatu sistem atau produk sehingga merasa "dekat" dengan sistem atau produk tersebut (Xu dkk., 2017). Di situasi pandemi ini, sistem pembayaran digital memegang peran penting dan memberikan banyak manfaat dibandingkan dengan sistem pembayaran secara tunai atau konvensional.

Sistem pembayaran digital membuktikan bahwa sistem ini lebih efisien dan memiliki keberlangsungan jangka panjang untuk digunakan ke depannya. Selain itu, pandemi juga mendorong individu untuk menggunakan sistem pembayaran digital. Pengalaman ini kemudian yang mengkonfirmasi 
kekhawatiran yang mungkin timbul dari dalam individu terkait kemudahan, keamanan, dan perlindungan yang diberikan oleh penyedia jasa pembayaran.

Apabila kekhawatiran individu atas suatu sistem tidak terbukti, maka kemungkinan individu akan terus menggunakan sistem yang dianggap lebih mudah, aman, dan memberikan nilai tambah dibandingkan dengan sistem terdahulu, dalam hal ini pembayaran tunai (Greenacre \& Akbar, 2019; Kim dkk., 2010; Xu dkk., 2017). Berdasarkan uraian di atas diperoleh hipotesis sebagai berikut:

$\mathrm{H}_{2}$ : Niat beralih dari sistem pembayaran konvensional menuju sistem pembayaran digital akan berpengaruh positif terhadap perilaku beralih dari sistem pembayaran konvensional menuju sistem pembayaran digital

\section{METODE PENELITIAN}

Penelitian ini adalah penelitian kuantitatif menggunakan data primer, yakni data yang diperoleh langsung dari responden berdasarkan pengalaman murni yang dialami oleh para responden (Cooper \& Schindler, 2014). Penelitian ini menguji hipotesis yang dibangun berdasarkan teori dan penelitian-penelitian terdahulu dengan menyesuaikan konteks di kondisi pandemi COVID-19 di Indonesia. Metode pengumpulan data menggunakan kuesioner yang disebarkan secara daring. Responden mengisi kuesioner dan melakukan pengumpulan ketika pengisian sudah selesai, kemudian secara otomatis data akan terekam dan dapat diakses oleh peneliti.

Populasi penelitian ini adalah seluruh masyarakat di Indonesia yang sudah pernah menggunakan sistem pembayaran digital baik dengan berbelanja online maupun menggunakan kartu debet, kredit, atau dompet digital selama pandemi COVID-19. Sampel penelitian adalah seseorang yang pernah melakukan transaksi online menggunakan sistem pembayaran digital di masa pandemi COVID-19.
Metode pengambilan sampel adalah purposive sampling karena ditetapkan kriteria tertentu yang harus dipenuhi untuk menjadi responden dalam penelitian ini (Sekaran \& Bougie, 2016). Kriteria yang harus dipenuhi adalah responden harus sudah pernah menggunakan sistem pembayaran nontunai selama pandemi COVID-19. Adapun sistem pembayaran nontunai yang digunakan antara lain kartu debet, kartu kredit, dompet digital, dan sistem pembayaran nontunai lainnya. Sebanyak 100 responden diperoleh dalam penelitian ini yang sebagian besar adalah generasi $\mathrm{Z}$ ( $<23$ tahun; 51\%) dan diikuti dengan generasi milenial (24-39 tahun; 49\%), terdiri dari 37 laki-laki dan 63 perempuan dengan tingkat pendidikan ratarata adalah sarjana.

Pemilihan jumlah sampel untuk pengujian SEM disesuaikan dengan kerumitan model dan jumlah konstruk penelitian. Apabila jumlah konstruk variabel adalah $\leq 5$, maka jumlah sampel minimumnya adalah 100 (Hair dkk., 2019).

Variabel diukur menggunakan kuesioner dengan skala Likert 1-5 (sangat tidak setuju hingga sangat setuju) dengan total 15 item pernyataan. Kuesioner sistem pembayaran elektronik diadopsi dari Kim dkk. (2010) yang berisi pernyataan pernah menggunakan sistem pembayaran digital saat ini dan keyakinan bahwa sistem digital akan terus berkembang. Kuesioner niat beralih (switching intention) berisi pernyataan sikap individu terhadap penggunaan sistem pembayaran digital di masa yang akan datang serta kepuasan yang dirasakan oleh individu sehingga meningkatkan keingintahuan yang lebih besar terhadap sistem pembayaran digital yang lain. Kuesioner perilaku beralih (switching behaviour) berisi pernyataan tentang sikap mulai meninggalkan pembayaran tunai dan merasakan manfaat serta kepuasan yang diperoleh dari pembayaran digital. Kuesioner niat beralih dan perilaku beralih keduanya diadopsi dari Bansal \& Taylor (1999). Data kemudian 
diolah menggunakan SmartPLS (Hair dkk., 2014).

\section{HASIL DAN PEMBAHASAN}

Pengujian pertama yang dilakukan adalah untuk mengetahui validitas dan reliabilitas dari konstruk yang digunakan dalam penelitian ini. Uji validitas terpenuhi apabila skor AVE >0,5. Uji reliabilitas terpenuhi apabila composite reliability value $>0,7$ dan cronbach's alpha $>0,6$ (Hair dkk., 2011). Berdasarkan Tabel 1, diperoleh kesimpulan bahwa seluruh konstruk yang digunakan dalam penelitian ini adalah valid dan reliabel.

Tabel 1. Hasil Uji Validitas dan Reliabilitas

\begin{tabular}{lcccc}
\hline \multicolumn{1}{c}{ Variable } & Loadings & AVE & $\begin{array}{c}\text { Composite } \\
\text { Reliability }\end{array}$ & $\begin{array}{c}\text { Cronbach's } \\
\text { Alpha }\end{array}$ \\
\hline $\begin{array}{l}\text { Penggunaan EPS (EPS) } \\
\text { USE1 }\end{array}$ & 0,779 & 0,567 & 0,794 & 0,620 \\
USE2 & 0,850 & & & \\
USE3 & 0,610 & & & \\
\hline Niat Beralih (NB) & & 0,640 & 0,841 & 0,763 \\
IB1 & 0,865 & & & \\
IB2 & 0,801 & & & \\
IB3 & 0,728 & & & \\
\hline Perilaku Beralih (PB) & & 0,655 & 0,884 & 0,827 \\
ALIH1 & 0.811 & & & \\
ALIH2 & 0.797 & & & \\
ALIH3 & 0.831 & & & \\
ALIH4 & 0.799 & & & \\
\hline Sum: Dann
\end{tabular}

Sumber: Data diolah (2020)

Pada structural equation model, ketepatan model diukur dengan melihat skor $\mathrm{R}^{2}$ dan adjusted $\mathrm{R}^{2}$. Skor $\mathrm{R}^{2}$ niat beralih dan perilaku beralih yakni sebesar 0,211 dan 0,213. Hal ini berarti bahwa penggunaan sistem pembayaran elektronik berpengaruh sebesar 20,3\% terhadap niat beralih dan niat beralih berpengaruh sebesar $20,5 \%$ terhadap perilaku beralih dari sistem konvensional menuju sistem pembayaran digital, sisanya dipengaruhi oleh variabel di luar penelitian.

Skor $\mathrm{R}^{2}$ sebesar 0,20 dalam studi keperilakuan dinilai sudah tinggi kecuali apabila tujuan penelitian adalah untuk mencari faktor-faktor pendorong kepuasan (Hair dkk., 2014). Hair dkk. (2014) memberikan penjelasan lebih lanjut bahwa apabila tujuan penelitian adalah untuk mencari faktor pendorong kesuksesan atas sesuatu, maka skor $\mathrm{R}^{2}$ yang semakin besar akan menghasilkan ketepatan yang semakin baik, misalnya lebih dari 0,75 . Oleh karena itu, skor $\mathrm{R}^{2}$ 0,211 dan 0,21 dinilai sudah mencukupi walaupun masuk kategori lemah. Hasil $\mathrm{R}^{2}$ dapat dilihat pada Tabel 2.

Tabel 2. Hasil $\mathrm{R}^{2}$

\begin{tabular}{lcc}
\hline \multicolumn{1}{c}{ Variable } & $\mathbf{R}^{\mathbf{2}}$ & Adjusted $\mathbf{R}^{\mathbf{2}}$ \\
\hline Niat beralih & 0,211 & 0,203 \\
Perilaku beralih & 0,213 & 0,205 \\
\hline
\end{tabular}

Sumber: Data diolah (2020)

Selanjutnya adalah pengujian hipotesis. Hasil uji hipotesis (Tabel 3) menunjukkan bahwa seluruh hipotesis dalam penelitian ini terdukung. Penggunaan sistem pembayaran elektronik berpengaruh positif signifikan terhadap niat beralih $\left(\mathrm{H}_{1}\right)$ dan niat beralih dari sistem pembayaran konvensional menuju pembayaran digital berpengaruh positif dan signifikan terhadap perilaku berpindah dari sistem pembayaran konvensional menuju sistem pembayaran digital $\left(\mathrm{H}_{2}\right)$. 
Tabel 3. Hasil Uji Hipotesis

\begin{tabular}{lccc}
\hline \multicolumn{1}{c}{ Hypotheses } & Path Coefficient & P-value & Conclusion \\
\hline $\mathrm{H}_{1}(\mathrm{EPS} \rightarrow \mathrm{NB})$ & $0,459^{* *}$ & 0,000 & Supported \\
$\mathrm{H}_{2}(\mathrm{NB} \rightarrow \mathrm{PB})$ & $0,452^{* *}$ & 0,000 & Supported \\
\hline
\end{tabular}

Sumber: Data diolah (2020)

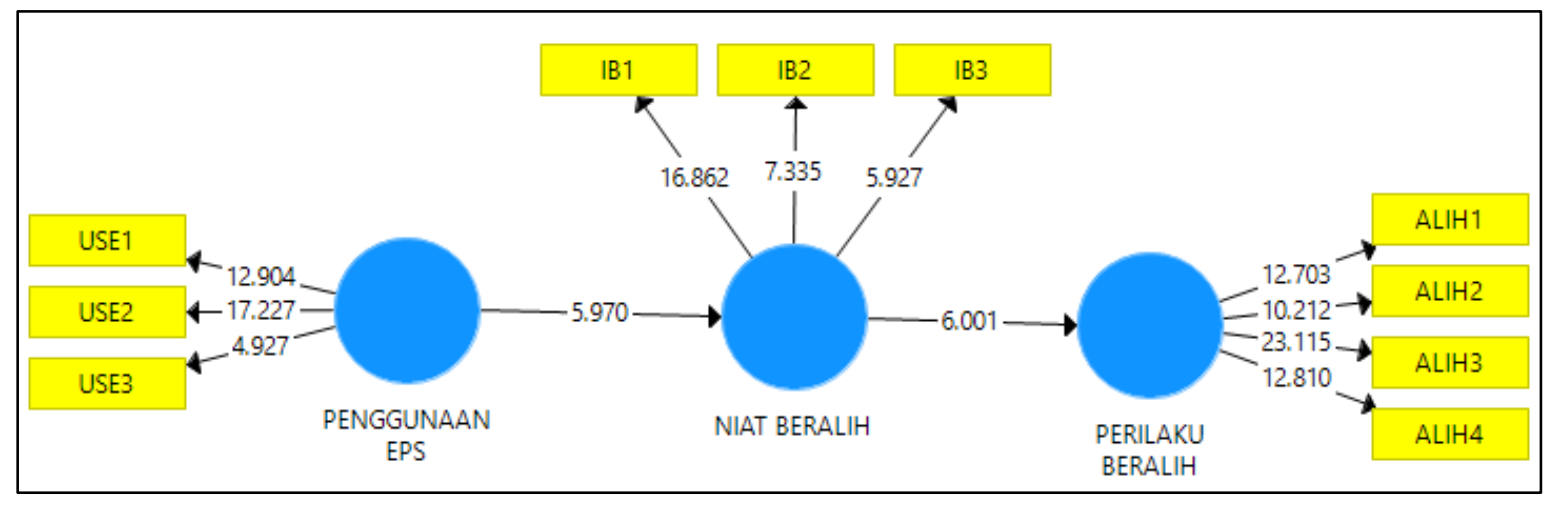

Gambar 2. Hasil Pengujian Hipotesis

\section{SIMPULAN DAN SARAN}

Kondisi pandemi COVID-19 yang berlangsung lebih dari satu tahun di Indonesia mengakibatkan beberapa perilaku individu berubah, termasuk dalam hal penggunaan sistem pembayaran. Hal ini didukung dengan adanya peningkatan penggunaan sistem pembayaran digital dan transaksi online sebesar $37 \%$ dan $66 \%$ di sepanjang tahun 2019 (Ulya, 2020). Adanya pandemi menyebabkan terbatasnya mobilitas masyarakat sehingga alternatif pembayaran elektronik banyak digunakan dibandingkan dengan pembayaran konvensional, begitu pula dengan berbelanja online (Badan Pusat Statistik, 2020a).

Sistem pembayaran digital menjadi alternatif yang tepat saat pandemi dikarenakan mudah untuk digunakan, fleksibel, dan tidak terbatas tempat dan waktu (Alaeddin dkk., 2018; Iradianty \& Aditya, 2020). Selain itu, pembayaran digital atau elektronik mempermudah transaksi karena tidak mengharuskan individu untuk keluar rumah dan berinteraksi dengan orang lain sesuai dengan kebijakan pemerintah di era pandemi ini.

Penggunaan sistem pembayaran elektronik selama pandemi, dalam penelitian ini didukung dengan analisis statistik bahwa hal tersebut dapat mendorong niat beralih individu pada sistem pembayaran digital. Niat beralih tersebut juga berpengaruh positif signifikan pada perilaku beralih menuju sistem pembayaran digital. Hal ini mendukung teori dan penelitian terdahulu bahwa pengalaman yang dirasakan individu saat menggunakan sistem pembayaran digital sesuai dengan harapan yang diinginkan sehingga dapat mendorong niat beralih hingga perilaku beralih (Ajzen, 1991; Battacherjee, 2001; Hardilawati, 2020; Sagayarani, 2017).

Hasil penelitian ini juga mengindikasikan bahwa setelah pandemi berlalu, bukan tidak mungkin masyarakat akan perlahan meninggalkan pembayaran tunai atau konvensional dan beralih ke sistem pembayaran digital. Tidak dapat dipungkiri bahwa sistem pembayaran digital lebih memberikan banyak kemudahan dan tawaran potongan harga yang menarik, khususnya bagi generasi $\mathrm{Z}$ dan milenial (Fabris, 2019; Kumari \& Khanna, 2017; Muthurasu \& Suganthi, 2019).

Penelitian selanjutnya dapat menganalisis perkembangan sistem pembayaran digital di era pascapandemi 
dan menggunakan variabel lain yang belum banyak dibahas dalam penelitian ini. Penelitian selanjutnya juga dapat menggunakan ukuran sampel yang lebih luas atau melakukan studi eksploratif terhadap faktor-faktor yang mendorong atau menghambat perkembangan sistem pembayaran digital dalam rangka mewujudkan masyarakat nontunai di tahun 2024 mendatang sesuai dengan program Bank Indonesia.

\section{REFERENSI}

Ajzen, I. (1991). The Theory of Planned Behavior. Organizational Behavior and Human Decision Processes, 50, 179-211. https://doi.org/10.1080/10410236. 2018.1493416

Alaeddin, O., Rana, A., Zainudin, Z., \& Kamarudin, F. (2018). From physical to digital: Investigating consumer behaviour of switching to mobile wallet. Polish Journal of Management Studies. https://doi.org/10.17512/pjms.201 8.17.2.02

Astuti, Y., \& Eliana. (2019). Perilaku Switching Behavior Pengguna Electronic Commerce (eCeommerce) di Kota Langsa dengan Model Migrasi Konsumen Push, Pull Mooring. SIMEN (Akuntansi Dan Manajemen) STIES, 10(1), 9-21.

Badan Pusat Statistik. (2020a). Analisis Big Data di Tengah Masa Adaptasi Baru. Jakarta: BPS RI.

Badan Pusat Statistik. (2020b). Hasil Survei Sosial Demografi Dampak COVID-19. Jakarta: BPS RI.

Bansal, H. S., \& Taylor, S. F. (1999). The service provider switching model (spsm) a model of consumer switching behavior in the services industry. Journal of service Research, 2(2), 200-218.

Battacherjee, A. (2001). Understanding information systems continuance: An expectation-confirmation model. MIS Quarterly, 25(3), 351370.

Chellapalli, T., \& Kumar, D. V. S. (2020). Role of customer perceptions in the usage of electronic payment systems. International Journal of Scientific and Technology Research, 9(2), 4336-4340.

Cooper, D. R., \& Schindler, P. S. (2014). Business Research Methods, 12th ed. New York: McGrawHill/Irwin.

Crowe, M. D., Schuh, S. D., \& Stavins, J. (2011). Consumer Behavior and Payment Choice: a Conference Summary. SSRN Electronic Journal, (06), 1-27. https://doi.org/10.2139/ssrn.91787 0

Fabris, N. (2019). Cashless Society - The Future of Money or a Utopia? Journal of Central Banking Theory and Practice, 8(1), 53-66. https://doi.org/10.2478/jcbtp2019-0003

Greenacre, L., \& Akbar, S. (2019). The impact of payment method on shopping behaviour among low income consumers. Journal of Retailing and Consumer Services, 47 87-93. https://doi.org/10.1016/j.jretconse r.2018.11.004

Hair, J. F., Ringle, C. M., \& Sarstedt, M. (2011). PLS-SEM: Indeed a Silver Bullet. The Journal of Marketing Theory and Practice, 19(2), 139152. https://doi.org/10.2753/MTP10696679190202

Hair, J. F., Sarstedt, M., Hopkins, L., \& Kuppelwieser, V. G. (2014). Partial least squares structural equation modeling (PLS-SEM): An emerging tool in business research. European Business Review, 26(2), 106-121. https://doi.org/10.1108/EBR-102013-0128 
Hair, J. F., Black, W. C., Babin, B. J., \& Anderson, R. E. (2019). Multivariate Data Analysis. https://doi.org/10.1002/97811194 09137.ch4

Han, H., Kim, W., \& Sean, S. (2011). International Journal of Hospitality Management Switching intention model development: Role of service performances, customer satisfaction, and switching barriers in the hotel industry. International Journal of Hospitality Management, 30(3), 619-629. https://doi.org/10.1016/j.ijhm.201 0.11 .006

Hardilawati, W. L. (2020). Strategi Bertahan UMKM di Tengah Pandemi Covid-19. Jurnal Akuntansi \& Ekonomika, 10(1), 89-98.

Iradianty, A., \& Aditya, B. R. (2020). Indonesian Student Perception in Digital Payment. Jurnal Manajemen Bisnis, 17(4), 518530.

https://doi.org/10.38043/jmb.v17i 4.2713

Jaya, L. (2016). Faktor-Faktor yang Mempengaruhi Customer Switching Behavior dalam Industri Retail Banking pada Bank BCA. Jurnal Bisnis Dan Manajemen, 52(11), 115-141.

Kim, C., Tao, W., Shin, N., \& Kim, K. S. (2010). An empirical study of customers' perceptions of security and trust in e-payment systems. Electronic Commerce Research and Applications, 9(1), 84-95. https://doi.org/10.1016/j.elerap.20 09.04.014

Kristensen, L. B. K., \& Solvoll, M. (2019). Digital payments for a digital generation: Disruptive technology in book and local newspaper industries. Nordic Journal of Media Studies, 1(1), 125-136. https://doi.org/10.2478/njms2019-0008.NORDICOM

Kumari, N., \& Khanna, J. (2017). Cashless Payment: A Behaviourial Change To Economic Growth. International Journal of Scientific Research and Education. https://doi.org/10.18535/ijsre/v5i0 7.03

Laudon, K. C., \& Laudon, J. P. (2018). Management Information Systems: Managing the Digital Firm, 15thGlobal ed. Uttar Pradesh: Pearson Education.

Lidwina, A. (2020). Nilai Transaksi Uang Elektronik Capai Rp 204,9 Triliun pada 2020. Katadata.co.id. Diakses dari https://databoks.katadata.co.id/dat apublish/2021/02/11/nilaitransaksi-uang-elektronik-capairp-2049-triliun-pada-2020

Lim, B., Lee, H., \& Kurnia, S. (2007). Exploring the reasons for a failure of electronic payment systems: A case study of an Australian company. Journal of Research and Practice in Information Technology, 39(4), 231-243.

Muthurasu, D. C., \& Suganthi, D. M. (2019). An Overview on Digital Library. Global Journal for Research Analysis, (October), 1-2. https://doi.org/10.36106/gjra/8906 567

Oney, E., Guven, G. O., \& Rizvi, W. H. (2017). The determinants of electronic payment systems usage from consumers' perspective. Economic Research-Ekonomska Istrazivanja, 30(1), 394-415. https://doi.org/10.1080/1331677X .2017 .1305791

Peha, J. M., \& Khamitov, I. M. (2004). PayCash: A secure efficient internet payment system. Electronic Commerce Research and Applications, 3(4), 381-388. https://doi.org/10.1016/j.elerap.20 04.06.001 
Sagayarani, D. (2017). Digital payments in India. IOSR Journal of Business and Management, 9(November), 28-33.

Sekaran, U., \& Bougie, R. (2016). Research Methods for Business. West Sussex: John Wiley \& Sons.

Thiab, A. S., \& Yusoh, Z. I. M. (2018). Developing a framework for electronic payment systems, trust and security in Iraq. Journal of Engineering and Applied Sciences, 13(12), 4482-4492. https://doi.org/10.3923/jeasci.201 8.4482 .4492

Ulya, F. N. (2020). Gubernur BI: Selama Pandemi, Transaksi Digital Naik 37,8 Persen. Kompas.com. Diaskes dari

https://money.kompas.com/read/2 020/09/29/154300526/gubernurbi--selama-pandemi-transaksidigital-naik-37-8-persen?page $=$ all
Urs, B. A. (2015). Security Issues and Solutions in E-Payment Systems. Fiat Iustitia, 21-28.

Xu, F., Tian, M., Ayala, B. R., Xu, G., \& Shen, W. (2017). Understanding Chinese users' switching behaviour of cloud storage services Introduction. The Electronic Library, 35(2), 214232.

https://doi.org/10.1300/J105v09n0 2_12

Zhang, J., Luximon, Y., \& Song, Y. (2019). The role of consumers' perceived security, perceived control, interface design features, and conscientiousness in continuous use of mobile payment services. Sustainability (Switzerland), 11(23). https://doi.org/10.3390/su1123684 3 
